\title{
THE NEED FOR ACCURATE RISK PREDICTION MODELS FOR ROAD MAPPING, SHARED DECISION MAKING AND CARE PLANNING FOR THE ELDERLY WITH ADVANCED CHRONIC KIDNEY DISEASE
}

\author{
Marijke Stryckers, Evi V Nagler, Wim Van Biesen \\ Renal Division Ghent University Hospital, Ghent Belgium
}

Corresponding Author: Evi V.T. Nagler, Renal Division, Department of Internal Medicine, Ghent University Hospital, De Pintelaan 185, 9000 Gent, Belgium; tel: +32 9332 0417; fax: +32 9332 3847; e-mail: evi.nagler@ugent.be

\begin{abstract}
As people age, chronic kidney disease becomes more common, but it rarely leads to end-stage kidney disease. When it does, the choice between dialysis and conservative care can be daunting, as much depends on life expectancy and personal expectations of medical care. Shared decision making implies adequately informing patients about their options, and facilitating deliberation of the available information, such that decisions are tailored to the individual's values and preferences. Accurate estimations of one's risk of progression to end-stage kidney disease and death with or without dialysis are essential for shared decision making to be effective. Formal risk prediction models can help, provided they are externally validated, well-calibrated and discriminative; include unambiguous and measureable variables; and come with readily applicable equations or scores. Reliable, externally validated risk prediction models for progression of chronic kidney disease to end-stage kidney disease or mortality in frail elderly with or without chronic kidney disease are scant. Within this paper, we discuss a number of promising models, highlighting both the strengths and limitations physicians should understand for using them judiciously, and emphasize the need for external validation over new development for further advancing the field.
\end{abstract}

Keywords: Prognosis; Proportional Hazard models; Logistic Models; Aged; Renal Insufficiency, Chronic

\section{Introduction}

The prevalence of Chronic Kidney Disease (CKD) increases with age, but few of the elderly actually progress to End Stage Kidney Disease (ESKD) [1-5]. During the past decade and partly fuelled by the KDIGO classification of CKD, many have started questioning whether in the elderly, decreased estimated glomerular filtration rate (eGFR) should really be labelled as a "disease" at all [6]. Simultaneously, a tendency to start renal replacement therapy (RRT) at higher eGFR thresholds, has resulted in a spectacular increase in older people starting dialysis $[7,8]$. Strikingly, the higher incidence of RRT in the elderly has been mirrored by an increasing number opting to withdraw from dialysis [9]. Despite large variation in attitudes between regions [10], the idea of conservative care has been gaining traction [1113]. As a consequence, both nephrologists and patients are currently struggling with how to approach advanced CKD.

A thematic analysis of disease trajectory experiences in elderly patients diagnosed with CKD revealed different themes that should be addressed to improve the care for this population: patients were shocked with their being labelled as having a serious disease, and were anxious about their prognosis; nephrologists felt uncertain about what and how to explain the complexity of the condition, and how to predict and steer future events; patients were 
eager to discuss eventual advanced care planning and/or need for dialysis, whereas nephrologists felt very uncomfortable and tended to avoid discussing likely negative aspects about their future [14].

Counselling older people with advanced CKD $\left(e G F R<45 \mathrm{ml} / \mathrm{min} / 1.73 \mathrm{~m}^{2}\right)$ requires reliable estimates of an individuals' absolute probability of death within a given time frame, both with and without starting dialysis. Furthermore, it requires accurate assessment of an individuals' absolute probability of progression to ESKD and eventual need for RRT. Predicting risk of progression to ESKD needs to take into account the competing risk of death to provide relevant information, whereas predicting death is hampered by the fact that developing ESKD in itself is a powerful predictor for mortality. Predicting progression is also challenging because GFR decline may not be linear [15], and rapid decline may occur unpredictably if associated with acute kidney injury [16]. This is especially true for older people who are at greater risk of acute kidney injury because of the high prevalence of frailty and other long-term term conditions [17].

First, correctly identifying patients likely to die early regardless of whether RRT is started, may avoid the unnecessary anxiety induced by preparing for dialysis, and the burden of dialysis itself. Conversely, in patients correctly identified as those who will reach ESKD long before dying, shared decisions on management, require counselling patients and families on different treatment options (haemodialysis, peritoneal dialysis, home-based vs hospital-based dialysis modality, conservative care), balancing quality versus quantity of life. Second, a robust method for identifying those at high risk of progression is necessary to focus renoprotective therapy to those who will benefit from it. Last, correctly estimating risk of death after starting RRT may provide a more accurate perception of the desirability of starting dialysis.

Within this paper we will try to construct an algorithm that helps in planning the nephrological care of elderly people with advanced CKD. We will discuss its potential use in clinical shared decision making, and its potential pitfalls and drawbacks.

\section{Shared decision making}

Over the last years, shared decision making has been forwarded as an important instrument to improve quality of care [18]. In contrast to the conventional paternalistic approach to medical decision making in which the physician decides what is best for the patient, shared decision making tries to involve the opinion, values and expectations of the patient in the process. For it to be effective, three steps are essential (Figure 1). The first step encompasses informing the patient about the different available options. The expected or most likely outcomes and eventual dangers of these different options should be clearly explained. In the setting of the elderly with advanced CKD, prediction of the outcomes 'mortality' and 'progression to ESKD' is prime for informing the process of shared decision making. During the past decade, there have been several attempts at developing risk prediction models, combining multiple demographic (e.g. age, sex) and clinical characteristics (e.g. medical history, physical examination results) to estimate individual risk of for each of these situations in the elderly (see below).

Several aspects might jeopardize information transfer. First, the correct information on the expected outcome of the different options might simply not be available, or might not be available for the specific population the patient belongs to (generalizability, external validity). This might be especially problematic in elderly patients with advanced CKD, as both elderly and patients with advanced CKD are mostly excluded from studies, and trials in these people are scant. Unfortunately, data from the general population, or even from the elderly without CKD or the non-elderly with CKD, are not readily translated to the elderly with CKD. Applying prognostic models developed in the general population to elderly patients with advanced CKD may result in overoptimistic prognosis, and pointless technical investigations and care.

Second, the information can be transferred in a biased, non-neutral way. Some treatment routines are so embedded in the structure and paths of care that everybody accepts them as the only possible way, leaving no room for alternatives. Accordingly, information on the alternative options is coloured by non-verbal (or even verbal) signs of disapproval 


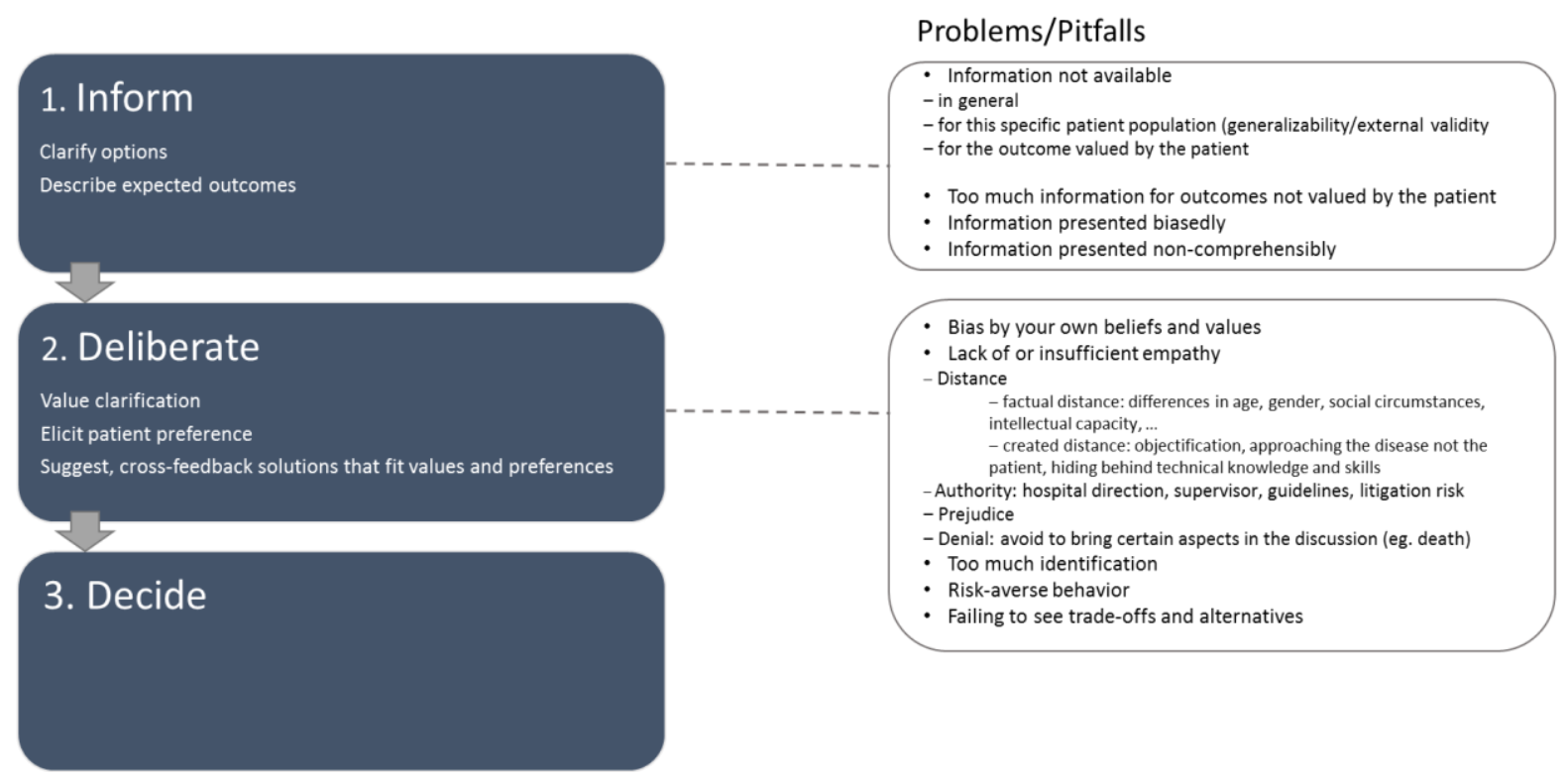

Figure 1 - Shared decision making in steps

Third, the information is often transferred in a way the patient does not understand. It is very difficult to transfer information on probabilities [19] and the uncertainty surrounding them to lay people, and even physicians and healthcare professionals may struggle to understand them [20]. In this era of digitalisation, it is becoming increasingly straightforward to present data in any imaginable graphical format. However, there is limited evidence on which presentations work best, and how these visualisations are processed and understood by the audience [21]. There is some evidence that graphical presentations should be adapted to the target audience, depending upon numeracy and health literacy, and digital tools can help to make these conversions. However, whatever tool or visualisation used, it reduces information from what is already a best guess. The resulting situation is that we are discussing facts that, though objective in themselves, are surrounded by a great degree of uncertainty, leaving ample room for subjective interpretation of the indeterminacy of the future presented. As such, some patients will opt for lowers odds than others. Experiments in the field of decision making on dialysis modality highlight that patients tend to be strongly influenced by stories of other patients [22] and far less by the same information provided by a physician.

Fourth, information on outcomes that matter to the patient might not be available, whereas ample information is provided on outcomes that do not matter to the patient [23]. Recently, the SONG project tried to establish a core outcome set for patients on haemodialysis [24]. SONG clarified that most studies use outcomes that are not patient relevant, whereas outcomes that do have value are rarely studied. In 2011, a comparable initiative was taken by the National Institute of Aging. They proposed that studies in this domain should focus on outcomes including measures of pain, fatigue, physical and mental functioning, social roles, daily activities, disease burden, and caregiver burden [25].

A next step in the shared decision making process is the deliberation of the available information. In this step, the physician needs to explore the patients' wishes, expectations, and values and elicit opinion on different potential scenarios. In this stage, empathy or the skill to view the situation through the eyes of the patient, is a necessary property for the medical team. The deliberation can be flawed if sufficient empathy is lacking, and result in the physician's rather than the patient's wish is followed. Empathy can be reduced through distance, either factual - substantial difference in age or different social backgrounds - or created, e.g. by a tendency to see the patient as an object or a case rather than as a person with distinct values and experiences. Empathy can also be endangered by authority, which not only comprises the supervisor or hospital board expecting the patient to start dialysis, but also 
existing guidelines, or fear for litigation. Furthermore, prejudice and denial can compromise open and empathic discussion with the patient. Many physicians find it a major challenge to discuss death with their patients, and will therefore try to avoid these discussions by denying or minimizing risk of death [26], so that patients are presented with unrealistic perspectives. The last step is the actual decision making. Studies indicate that most patients want to be informed about the different options available, but that most will state in one form or another, that the physician should take the decision for them (doctor, what would you do). As discussed above, this does not imply that physicians can simply do as they please, but rather that they should take into account patients' desires and values, and use their clinical expertise to propose the solution or treatment most likely to result in an outcome the patient desires. This process requires not only empathy, but also insight in how available evidence is applicable to the particular situation of the individual patient, taking into account known comorbidities. It is flabbergasting to realize that for most provided guidance, there is a complete lack of external validity of the underlying evidence for most subpopulations the guideline refers to [27].
Risk prediction models: definition and assessment pitfalls

In a model of shared decision making, accurate and unbiased information on the fate of the individual is essential.

Risk prediction models aim to objectively predict the risk of a future outcome, e.g. mortality or ESKD, based on a set of variables available at the time the prediction is made. Essentially, each variable is awarded a weight - or coefficient - and combined in a mathematical rule to predict an outcome of interest. Similar to weather-forecasts though, it is not because intricate models exist, that they produce reliable estimates of what will happen in reality.

Evaluating the quality, generalizability and utility of risk prediction models poses certain challenges that are both interesting from a methodological point of view and crucial to understand for the clinician wanting to use such models for informing their clinical practice. Some of the methods for assessing model performance can be quite daunting and lead to misinterpretation or overly confident conclusions around accuracy, reliability and generalizability of the predictions (Table 1).

Table 1

Risk prediction model assessment: pitfalls and solutions

\begin{tabular}{|c|c|c|}
\hline Model assessment pitfalls & Limitations & Solution \\
\hline Model only internal validated & $\begin{array}{l}\text { Produces overly optimistic view of } \\
\text { model performance }\end{array}$ & $\begin{array}{l}\text { External validation in cohorts } \\
\text { similar to target population }\end{array}$ \\
\hline $\begin{array}{l}\text { C-statistic as measure of } \\
\text { discrimination }\end{array}$ & $\begin{array}{l}\text { No practical meaning } \\
\text { No differential weighting of } \\
\text { misclassification errors } \\
\text { Heavily dependent on risk factor } \\
\text { distribution }\end{array}$ & $\begin{array}{l}\text { Positive predictive values } \\
\text { Negative predictive values }\end{array}$ \\
\hline $\begin{array}{l}\text { Vague description and } \\
\text { dichotomized risk predictors }\end{array}$ & $\begin{array}{l}\text { Classification errors } \\
\text { Information reduction and increase in } \\
\text { unmeasured variability }\end{array}$ & $\begin{array}{l}\text { Clarity of description } \\
\text { Layered risk predictors }\end{array}$ \\
\hline $\begin{array}{l}\text { Risk scores with coefficients } \\
\text { rounded to nearest integer }\end{array}$ & $\begin{array}{l}\text { Information reduction and } \\
\text { unmeasured variability }\end{array}$ & $\begin{array}{l}\text { Risk calculators, apps, } \\
\text { integration in electronic health } \\
\text { record }\end{array}$ \\
\hline
\end{tabular}

1/First of all, a model needs to be tested in a group of people that was not used to develop the model, it needs to be externally validated [28]. Why is that? Well of course, developing a model means mimicking the data as much as reasonably possible and so, often the resulting model will be reasonably good at predicting whatever it is that we want it to predict. As a consequence, conclusions based on performance measures calculated in the same cohort as the one that was used to develop the model, will necessarily produce overly optimistic 
conclusions of a model's accuracy [29]. Ideally, validation is done by investigators who were not involved in the model development process.

2/The performance of a risk prediction model is commonly assessed by testing its calibration - the agreement of observed and predicted event rates - and discrimination - the ability to distinguish individuals who will develop the outcome of interest from those who will not. Investigators often use the C-statistic as a global measure of model discrimination, ranging from 0.5 (random concordance) to 1 (perfect concordance). The C-statistic can be seen as the area under the curve of the receiver operating characteristic curve, be it with several important limitations [29].

For one thing, it is a single number that does not really have a practical interpretation. Sure, if it equals 1 , the model is perfect, and if it equals 0.5 , throw it in the bin; but for any number in between, it has no practical meaning attached to it. It does not convey the implications of the misclassification errors that can occur (predicting an individual who experiences an event to be at low risk; predicting an individual who does not experience an event to be at high risk) [29]. For that we need positive and negative predictive values, which do have a direct clinical meaning, but sadly these are seldom reported.

Secondly, the value of the $\mathrm{C}$ statistic depends not only on the model being assessed, but also on the distribution of risk factors in the sample to which it is applied. For example, if eGFR is an important risk factor, the same model can appear to perform much better when applied to a cohort with a wide eGFR range than when it is applied to a cohort with a narrow eGFR range. Finally, the $C$ statistic is only a measure of discrimination, so it provides no information regarding whether the overall magnitude of risk is predicted accurately.

For that we need to look at calibration measures, which assess how accurately the model's predictions match overall observed event rates. In other words, we look at the agreement between what we predict and what we observe. Without going into detail, we can safely state that sadly again, calibration measures are often omitted [30, 31].

3/ For a model to be useful in practice, it needs to include variables that are readily avai- lable, well-defined and measurable. Clear definitions of individual risk predictors are necessary to ensure inter-rater reliability. The presence or absence of "diabetes", for example, can be interpreted differently by different raters. Does it apply to everyone meeting international criteria, even if transient or perfectly controlled with limited diet restrictions; or is it limited to patients treated with insulin? The same problem arises for many commonly used predictors, such as cardiovascular disease, peripheral vascular disease, cancer or chronic lung disease: if not explicitly described how these categorical variables should be measured, they can induce substantial variation in scoring, and thus importantly influence model performance [32].

4/ For a model to be applicable in practice, it needs to come with an actual equation that allows straightforward calculation of an individual's absolute risk of the outcome of interest. To this day, researchers often still opt to create risk scores, which basically transform the model parameters to integers that can be summed to derive a global risk prediction for that individual patient. A classic example we are all very familiar with is the CHADS-Vasc score, which allocates points for age, hypertension, diabetes etc., and relates that sum to an absolute annual risk of stroke in atrial fibrillation. With smartphones being in everyone's pockets and emergence of companies specializing in developing apps for risk calculation, there seems to be increasingly less virtue in doing that. Instead of simplifying models to allow risk calculation without computer assistance, attention is probably better refocussed to model visualisation to boost uptake and efficient communication of their results [21].

\section{Available risk prediction scoring systems for elderly with advanced CKD}

\section{Progression to ESKD}

Several prospective [33-35] and retrospective [4, 5, 36-38] cohort studies aimed to develop risk prediction scores based on identified risk factors for progression to ESKD. The Kidney Failure Risk Equation (KFRE) initiative analysed data from Canadian adults with eGFR $10-59 \mathrm{ml} / \mathrm{min} / 1.73 \mathrm{~m}^{2}$ to develop the KFRE equation to predict the risk of ESKD at 2 and 5 
years [38]. Using 8 variables (age, sex, eGFR, albuminuria, serum calcium, serum phosphate, serum bicarbonate, and serum albumin) this score proved to have good discrimination capacity, both in development $(\mathrm{C}$ statistic $=0.92)$ and in the validation cohorts $(\mathrm{C}$ statistic $=0.84)$, and reducing the number of variables further down to 4 easily available parameters (age, gender, eGFR and albuminuria) did not substantially alter the discriminative capacity performed similarly (C statistic $=0.91$ and 0.84 in development and validation cohorts, respectively) [39]. An external validation was carried out in a Dutch cohort with stage 3-5 CKD, demonstrating that the scores performed well to predict 5-year risk (C statistic 0.89 and 0.88 , respectively) and also had a good calibration (difference between predicted and observed risk $4.0 \%$ and $7.1 \%$, respectively). In an external dataset with over 700.000 patients, the 4-variable KFRE achieved excellent discrimination (pooled $\mathrm{C}$ statistic 0.90 at 2 years and 0.88 at 5 years), although the KFREs tended to overestimate risk in some non-North American cohorts. Addition of a calibration factor improved calibration in 12/15 and 10/13 non-North American cohorts at 2 and 5 years, respectively [40]. These data seem to indicate that the 4 variable KFRE (with the use of a calibration factor for non-American cohorts) is suitable to estimate the risk for evolution to ESKD in this population.

\section{Mortality risk in CKD}

Since 2012, two high quality systematic reviews, one including models predicting death in elderly people [41] and one predicting death in people with CKD [42] have been published on the topic. Starting from the search strategies of these papers, we identified 24 publications including 31 risk prediction models, of which 15 models target elderly people in general [4355], 4 elderly people with CKD 3-5 [5, 56, 57], and 12 elderly people with end-stage kidney disease (ESKD) [58-63]. Only three models were developed or validated in Western Europe. The most commonly included final predictors of death were age, sex, functional status, heart failure, malignancy and diabetes. Although most models included parameters of frailty, only one model was specifically developed within a frail elderly patient group [43]. As a consequence, it would be safe to consider using an additional scoring system for frailty in patients with a low predicted risk for mortality by any of these scores.

Another caveat is that external validation was mostly not available, and as far as it was, it was mostly done by the same investigators that had developed the model, and in patients very similar to the ones included in the development cohort. In addition, presence of comorbidities was based either on self-report or on coding within administrative databases. Both methods can induce misclassification as criteria might not be clear or well described. This can substantially reduce predictive performance, especially upon generalisation to patient groups external to the ones used for model development. In general, model performance was moderate at best, with only 1 model achieving a cstatistic of $>0.8$ [49], and confidence intervals were generally not provided. The Bansal risk prediction model predicts the absolute probability of death within five years for older people with CKD stage 3 through 5 not yet treated with dialysis, provides measures of predictive performance and was externally validated in a large cohort of representative patients, except that the overwhelming majority was able to live independently [56]. The model has a reasonable calibration and model discrimination in both the development $(0.72 ; 95 \%$ CI 0.68 to 0.74$)$ and validation cohort (0.69; $95 \%$ $\mathrm{Cl} 0.64$ to 0.74 ). As the validation cohort might not be representative for cohorts containing frail patients, and as it has been well established that frailty is a prevalent condition in patients with advanced CKD ( $\mathrm{eGFR}<45 \mathrm{ml} / \mathrm{min}$ ) [64], it is absolutely mandatory to combine the Bansal score with a score for frailty when Bansal score is low, as in this setting mortality risk will be governed by frailty rather than by traditional risk factors. However, it has been advocated that frailty is an additional risk factor for mortality, on top and independent of other traditional risk factors [65]. As such, a high predicted mortality with the Bansal score will deliver a reliable result even in a frail patient.

Mortality risk in ESKD

One risk prediction model based on the REIN-registry data estimates risk of death at 
three months in older people with ESKD starting with dialysis [60]. The cohort is representative for elderly patients starting dialysis, both in terms of age (at least 75 years old, with one in five $>85$ years) and in terms of comorbidity (heart failure 33\% and peripheral vascular disease $25 \%$ ). This risk prediction model includes 9 easily available predictors: age, sex, history of congestive heart failure, peripheral vascular disease, arrhythmia, cancer, severe behavioural disorder, mobility and baseline serum albumin concentration. The rate of death in the validation cohort increased with the score, indicating good calibration, but discrimination was moderate with a c-statistic in the internal validation cohort of 0.75 (95\% CI: 0.74-0.76). The model was further externally validated in a Flemish cohort [39], although the investigators slightly modified the score. Another risk prediction score based on the REIN-cohort data estimates risk of death at six months in older people with ESKD starting with dialysis [59]. The model was further externally validated in an American cohort [58] although again, investigators modified the score [58].

Floege and co-workers also developed a risk prediction model predicting mortality in patients starting dialysis based on the Framingham study model [66]. This model was than validated in an external cohort of the Dialysis Outcomes and Practices. Patterns (DOPPS), showing a moderate discrimination (c statistic of 0.68 to 0.79 depending upon geographic location). Although the score includes age, it has not been developed or validated in a cohort of elderly dialysis patients (mean age $64 \pm 14$ years), and the cohort did also not include peritoneal dialysis patients. Furthermore, the development cohort includes only patients who survived the first 3 months, whereas the validation cohort of DOPPS includes mainly prevalent patients. Both attributes make that the score is likely to be not very representative for the dilemma whether or not to start dialysis in the frail elderly, where exactly this risk of short term mortality during the initiation phase of dialysis is what needs to be predicted.

\section{Conclusions}

In conclusion, reliable, externally validated risk prediction models for progression of CKD to ESKD or mortality in frail elderly with or without CKD are necessary to inform shared decision making in the trajectory of the elderly with advanced CKD, but available models are scant. Physicians need to understand the limitations of these models so that they can be used appropriately. Next to understanding the models themselves, healthcare workers need to translate the available information to patients, and that in a way the patient can understand, and use the information to choose a trajectory of care most likely to achieve his/her goals and expectations, taking into account his individual needs. Rather than developing new models in a search for more sophisticated statistical models, we emphasize the importance of external validation by different investigators of those models in both frail and non-frail elderly patients to test their performance and applicability. In addition, more effort must go to developing strategies for translating the information such that it becomes digestible and understandable for all involved.

\section{REFERENCES}

1. Coresh J, Selvin E, Stevens LA, Manzi J, Kusek JW, Eggers P, et al. Prevalence of chronic kidney disease in the United States. Jama. 2007; 298(17): 2038-47.

2. Bruck K, Stel VS, Gambaro G, Hallan S, Volzke H, Arnlov J, et al. CKD Prevalence Varies across the European General Population. J Am Soc Nephrol. 2015; 27(7): 2135-47

3. Hallan SI, Dahl K, Oien CM, Grootendorst DC, Aasberg A, Holmen J, et al. Screening strategies for chronic kidney disease in the general population: follow-up of cross sectional health survey. BMJ. 2006; 333(7577): 1047.

4. Johnson ES, Thorp ML, Platt RW, Smith DH. Predicting the risk of dialysis and transplant among patients with CKD: a retrospective cohort study. Am J Kidney Dis. 2008; 52(4): 653-60.

5. Johnson ES, Thorp ML, Yang X, Charansonney OL, Smith DH. Predicting renal replacement therapy and mortality in CKD. Am J Kidney Dis. 2007; 50(4): 559-65.

6. Eknoyan G. Chronic kidney disease definition and classification: no need for a rush to judgment. Kidney Int. 2009; 75(10): 1015-8.

7. Noordzij M, Kramer A, Abad Diez JM, Alonso de la Torre R, Arcos Fuster E, Bikbov BT, et al. Renal replacement therapy in Europe: a summary of the 2011 ERA-EDTA Registry Annual Report. Clin Kidney J. 2014; 7(2): 227-38.

8. Clark WF, Na Y, Rosansky SJ, Sontrop JM, Macnab JJ, Glassock RJ, et al. Association between estimated glomerular filtration rate at initiation of dialysis and mortality. CMAJ. 2011; 183(1): 47-53. 
9. Ellwood AD, Jassal SV, Suri RS, Clark WF, Na Y, Moist LM. Early dialysis initiation and rates and timing of withdrawal from dialysis in Canada. Clin J Am Soc Nephrol. 2013; 8(2): 265-70.

10. van Biesen W, van de Luijtgaarden MW, Brown EA, Michel JP, van Munster BC, Jager KJ, et al. Nephrologists' perceptions regarding dialysis withdrawal and palliative care in Europe: lessons from a European Renal Best Practice survey. Nephrol Dial Transplant. 2015; 30(12): 1951-8.

11. Okamoto I, Tonkin-Crine S, Rayner H, Murtagh FE, Farrington K, Caskey F, et al. Conservative care for ESRD in the United Kingdom: a national survey. Clin J Am Soc Nephrol. 2015; 10(1): 120-6.

12. Murtagh FE, Marsh JE, Donohoe P, Ekbal NJ, Sheerin NS, Harris FE. Dialysis or not? A comparative survival study of patients over 75 years with chronic kidney disease stage 5. Nephrol Dial Transplant. 2007; 22(7): 1955-62.

13. Brown MA, Collett GK, Josland EA, Foote C, Li Q, Brennan FP. CKD in elderly patients managed without dialysis: survival, symptoms, and quality of life. Clin J Am Soc Nephrol. 2015; 10(2): 260-8.

14. Schell JO, Patel UD, Steinhauser KE, Ammarell N, Tulsky JA. Discussions of the kidney disease trajectory by elderly patients and nephrologists: a quailtative study. Am J Kidney Dis. 2012; 59(4): 495-503.

15. Li L, Astor BC, Lewis J, Hu B, Appel LJ, Lipkowitz MS, et al. Longitudinal progression trajectory of GFR among patients with CKD. Am J Kidney Dis. 2012; 59(4): 504-12.

16. D'Hoore E, Neirynck N, Schepers E, Vanholder R, Verbeke F, Van Thielen M, et al. Chronic kidney disease progression is mainly associated with nonrecovery of acute kidney injury. J Nephrol. 2015; 28(6): 709-16.

17. O'Hare AM, Choi AI, Bertenthal D, Bacchetti P, Garg AX, Kaufman JS, et al. Age affects outcomes in chronic kidney disease. J Am Soc Nephrol. 2007; 18(10): 2758-65.

18. Muthalagappan S, Johansson L, Kong WM, Brown EA. Dialysis or conservative care for frail older patients: ethics of shared decision-making. Nephrol Dial Transplant. 2013; 28(11): 2717-22.

19. Spiegelhalter D, Pearson M, Short I. Visualizing uncertainty about the future. Science. 2011; 333(6048): 1393-400.

20. Wegwarth O, Schwartz LM, Woloshin S, Gaissmaier W, Gigerenzer G. Do physicians understand cancer screening statistics? A national survey of primary care physicians in the United States. Ann Int Med. 2012; 156(5): 340-9.

21. Van Belle V, Van Calster B. Visualizing Risk Prediction Models. PloS one. 2015; 10(7): e0132614.

22. Winterbottom AE, Bekker HL, Conner M, Mooney AF. Patient stories about their dialysis experience biases others' choices regardless of doctor's advice: an experimental study. Nephrol Dial Transplant. 2012; 27(1): 325-31.

23. Nistor I, Bolignano D, Haller MC, Nagler E, van der Veer SN, Jager K, et al. Why creating standardized core outcome sets for chronic kidney disease will im- prove clinical practice. Nephrol Dial Transplant. 2015. doi: 10.1093/ndt/gfv365

24. Tong A, Manns B, Hemmelgarn B, Wheeler DC, Tugwell P, Winkelmayer WC, et al. Standardised outcomes in nephrology - Haemodialysis (SONGHD): study protocol for establishing a core outcome set in haemodialysis. Trials. 2015; 16: 364.

25. Universal health outcome measures for older persons with multiple chronic conditions. J Am Geriatr Soc. 2012; 60(12): 2333-41.

26. Boyd K, Murray SA. Why is talking about dying such a challenge? BMJ. 2014; 348: g3699.

27. McAlister FA, van Diepen S, Padwal RS, Johnson JA, Majumdar SR. How evidence-based are the recommendations in evidence-based guidelines? PLoS Med. 2007; 4(8): e250.

28. Altman DG, Vergouwe Y, Royston P, Moons KG. Prognosis and prognostic research: validating a prognostic model. Bmj. 2009; 338: b605.

29. Pencina MJ, D’Agostino RB, Sr. Evaluating discrimination of risk prediction models: The c statistic. Jama. 2015; 314(10): 1063-4.

30. Rigatto C, Sood MM, Tangri N. Risk prediction in chronic kidney disease: pitfalls and caveats. Current opinion in nephrology and hypertension. 2012; 21(6): 612-8.

31. Tangri N, Kitsios GD, Inker LA, Griffith J, Naimark DM, Walker S, et al. Risk prediction models for patients with chronic kidney disease: a systematic review. Ann Intern Med. 2013; 158(8): 596-603.

32. Moons KG, Altman DG, Reitsma JB, Ioannidis JP, Macaskill P, Steyerberg EW, et al. Transparent Reporting of a multivariable prediction model for Individual Prognosis or Diagnosis (TRIPOD): explanation and elaboration. Ann Intern Med. 2015; 162(1): W1-73.

33. Dalrymple LS, Katz R, Kestenbaum B, Shlipak MG, Sarnak MJ, Stehman-Breen C, et al. Chronic kidney disease and the risk of end-stage renal disease versus death. J Gen Intern Med. 2011; 26(4): 379-85.

34. De Nicola L, Minutolo R, Chiodini P, Borrelli S, Zoccali C, Postorino M, et al. The effect of increasing age on the prognosis of non-dialysis patients with chronic kidney disease receiving stable nephrology care. Kidney Int. 2012; 82(4): 482-8.

35. Faller B, Beuscart JB, Frimat L. Competing-risk analysis of death and dialysis initiation among elderly $(>/=80$ years) newly referred to nephrologists: a French prospective study. BMC Nephrol. 2013; 14: 103.

36. Drawz PE, Goswami P, Azem R, Babineau DC, Rahman M. A simple tool to predict end-stage renal disease within 1 year in elderly adults with advanced chronic kidney disease. J Am Geriatr Soc. 2013; 61(5): 762-8.

37. Obi Y, Kimura T, Nagasawa Y, Yamamoto R, Yasuda K, Sasaki K, et al. Impact of age and overt proteinuria on outcomes of stage 3 to 5 chronic kidney disease in a referred cohort. Clin J Am Soc Nephrol. 2010; 5(9): 1558-65.

38. Tangri N, Stevens LA, Griffith J, Tighiouart H, Djurdjev O, Naimark D, et al. A predictive model for 
progression of chronic kidney disease to kidney failure. Jama. 2011; 305(15): 1553-9.

39. Peeters MJ, van Zuilen AD, van den Brand JA, Bots ML, Blankestijn PJ, Wetzels JF. Validation of the kidney failure risk equation in European CKD patients. Nephrol Dial Transplant. 2013; 28(7): 1773-9.

40. Tangri N, Grams ME, Levey AS, Coresh J, Appel LJ, Astor BC, et al. Multinational Assessment of Accuracy of Equations for Predicting Risk of Kidney Failure: A Meta-analysis. Jama. 2016; 315(2): 164-74.

41. Yourman LC, Lee SJ, Schonberg MA, Widera EW, Smith AK. Prognostic indices for older adults: a systematic review. Jama. 2012; 307(2): 182-92.

42. Tangri N, Kitsios GD, Inker LA, Griffith J, Naimark DM, Walker S, et al. Risk prediction models for patients with chronic kidney disease: a systematic review. Ann Intern Med. 2013; 158(8): 596-603.

43. Carey EC, Covinsky KE, Lui LY, Eng C, Sands LP, Walter LC. Prediction of mortality in communityliving frail elderly people with long-term care needs. J Am Ger Soc. 2008; 56(1): 68-75.

44. Carey EC, Walter LC, Lindquist K, Covinsky KE. Development and validation of a functional morbiddity index to predict mortality in community-dwelling elders. J Gen Int Med. 2004; 19(10): 1027-33.

45. Gagne JJ, Glynn RJ, Avorn J, Levin R, Schneeweiss S. A combined comorbidity score predicted mortality in elderly patients better than existing scores. J Clin Epidem. 2011; 64(7): 749-59.

46. Han PK, Lee M, Reeve BB, Mariotto AB, Wang Z, Hays RD, et al. Development of a prognostic model for six-month mortality in older adults with declining health. J Pain Symptom Manag. 2012; 43(3): 527-39.

47. Inouye SK, Bogardus ST, Jr., Vitagliano G, Desai MM, Williams CS, Grady JN, et al. Burden of illness score for elderly persons: risk adjustment incorporating the cumulative impact of diseases, physiologic abnormalities, and functional impairments. Medical care. 2003; 41(1): 70-83.

48. Lee JS, Chau PP, Hui E, Chan F, Woo J. Survival prediction in nursing home residents using the Minimum Data Set subscales: ADL Self-Performance Hierarchy, Cognitive Performance and the Changes in Health, End-stage disease and Symptoms and Signs scales. Eur J Pub Health. 2009; 19(3): 308-12.

49. Lee SJ, Lindquist K, Segal MR, Covinsky KE. Development and validation of a prognostic index for 4year mortality in older adults. Jama. 2006; 295(7): 801-8.

50. Levine SK, Sachs GA, Jin L, Meltzer D. A prognostic model for 1-year mortality in older adults after hospital discharge. Am J Med. 2007; 120(5): 455-60.

51. Mazzaglia G, Roti L, Corsini G, Colombini A, Maciocco G, Marchionni N, et al. Screening of older community-dwelling people at risk for death and hospitalization: the Assistenza Socio-Sanitaria in Italia project. J Am Ger Soc. 2007; 55(12): 1955-60.

52. Porock D, Oliver DP, Zweig S, Rantz M, Mehr D, Madsen R, et al. Predicting death in the nursing home: development and validation of the 6-month Minimum Data Set mortality risk index. Journals Ger Series A. 2005; 60(4): 491-8.
53. Schonberg MA, Davis RB, McCarthy EP, Marcantonio ER. Index to predict 5-year mortality of community-dwelling adults aged 65 and older using data from the National Health Interview Survey. J Int Med. 2009; 24(10): 1115-22.

54. Sharifi F, Ghaderpanahi M, Fakhrzadeh H, Mirarefin M, Badamchizadeh Z, Tajalizadekhoob Y, et al. Older people's mortality index: development of a practical model for prediction of mortality in nursing homes (Kahrizak Elderly Study). Ger Geront Int. 2012; 12(1): 36-45.

55. Walter LC, Brand RJ, Counsell SR, Palmer RM, Landefeld CS, Fortinsky RH, et al. Development and validation of a prognostic index for 1-year mortality in older adults after hospitalization. Jama. 2001; 285(23): 2987-94.

56. Bansal N, Katz R, De Boer IH, Peralta CA, Fried LF, Siscovick DS, et al. Development and validation of a model to predict 5-year risk of death without ESRD among older adults with CKD. Clin J Am Soc Nephrol. 2015; 10(3): 363-71.

57. Weiss JW, Platt RW, Thorp ML, Yang X, Smith DH, Petrik A, et al. Predicting mortality in older adults with kidney disease: a pragmatic prediction model. J Am Ger Soc. 2015; 63(3): 508-15.

58. Cheung KL, Montez-Rath ME, Chertow GM, Winkelmayer WC, Periyakoil VS, Kurella Tamura M. Prognostic stratification in older adults commencing dialysis. Journals Geront Series A. 2014; 69(8): 1033-9.

59. Couchoud C, Labeeuw M, Moranne O, Allot V, Esnault V, Frimat L, et al. A clinical score to predict 6-month prognosis in elderly patients starting dialysis for end-stage renal disease. Nephrol Dial Transplant. 2009; 24(5): 1553-61.

60. Couchoud CG, Beuscart JB, Aldigier JC, Brunet PJ, Moranne OP. Development of a risk stratification algorithm to improve patient-centered care and decision making for incident elderly patients with endstage renal disease. Kidney Int. 2015; 88(5): 1178-86.

61. Liu J, Huang Z, Gilbertson DT, Foley RN, Collins AJ. An improved comorbidity index for outcome analyses among dialysis patients. Kidney Int. 2010; 77(2): 141-51.

62. Thamer M, Kaufman JS, Zhang Y, Zhang Q, Cotter DJ, Bang H. Predicting Early Death Among Elderly Dialysis Patients: Development and Validation of a Risk Score to Assist Shared Decision Making for Dialysis Initiation. Am J Kidney Dis. 2015; 66(6): 1024-32.

63. van Diepen M, Schroijen MA, Dekkers OM, Rotmans JI, Krediet RT, Boeschoten EW, et al. Predicting mortality in patients with diabetes starting dialysis. PloS one. 2014; 9(3): e89744.

64. McAdams-DeMarco MA, Law A, Salter ML, Boyarsky B, Gimenez L, Jaar BG, et al. Frailty as a novel predictor of mortality and hospitalization in individuals of all ages undergoing hemodialysis. J Am Geriatr Soc. 2013; 61(6): 896-901.

65. Rockwood K, Song X, MacKnight C, Bergman H, Hogan DB, McDowell I, et al. A global clinical measure of fitness and frailty in elderly people. CMAJ. 2005; 173(5): 489-95. 
66. Floege J, Gillespie IA, Kronenberg F, Anker SD, Gioni I, Richards S, et al. Development and validation of a predictive mortality risk score from a European hemodialysis cohort. Kidney Int. 2015; 87(5): 996-1008.

Резиме

\section{ПОТРЕБА ОД ПРЕЦИЗНИ МОДЕЛИ ЗА ПРЕДВИДУВАЊЕ РИЗИК, ЗАЕДНИЧКО ДОНЕСУВАЊЕ ОДЛУКИ И ПЛАНИРАЊЕ НЕГА НА ПОСТАРИ ЛИЦА СО НАПРЕДНА ХРОНИЧНА БУБРЕЖНА БОЛЕСТ}

\section{Маријке Стикерс, Еви В Наглер, Вим Ван Бисен}

Оддел за нефрологија, Универзитетска болница во Гент, Гент, Белгија

Како што стареат луѓето, хроничната бубрежна болест станува сѐ почеста, но ретко доведува до краен стадиум на бубрежна болест. Кога ќе се случи тоа, изборот помеѓу дијализа и конзервативна нега може да биде застрашувачки, бидејќи тоа многу зависи од животниот век и личните очекувања од медицинската нега. Заед- ничкото донесување одлуки подразбира соодветно информирање на пациентите за нивните можности, и олеснување на разгледувањето на достапните информации, така што одлуките се приспособени на вредностите и преференциите на поединецот. Точните процени за ризикот од прогресија до краен стадиум на бубрежна болест и смрт, со или без дијализа, се суштински за да биде ефикасно заедничкото донесување одлука. Формалните модели за предвидување ризик може да помогнат ако се надворешно потврдени, добро калибрирани и дискриминативни; ако вклучуваат недвосмислени и мерливи променливи; и ако доаѓаат со применливи равенки или резултати. Недоволни се сигурните, надворешно потврдени модели за предвидување ризик од прогресија на хроничната бубрежна болест до краен стадиум на бубрежна болест или смртност кај снемоштени стари лица со или без хронична бубрежна болест. Во рамките на овој труд, разгледуваме голем број надежни модели, истакнувајќи ги предностите и ограничувањата што треба да ги разберат лекарите за да ги користат разумно и да ја истакнуваат потребата од надворешна валидација преку нов развој за натамошно унапредување на полето.

Клучни зборови: прогноза, пропорционални модели на ризик, логистички модели, возрасни лица, бубрежна инсуфициенција, хронична 